\title{
Ichthyofauna in the XhimojayDam, State of Mexico
}

\section{Rodríguez-Varela Asela Del Carmen, Cruz-Gómez Adolfo, Vázquez-López Horacio, Karen Hernández-Pérez, Luis Roberto Palacios-Navarro}

Fish Ecology Laboratory, Faculty of Higher Study Iztacala, UNAM, Tlalnepantla, Mexico

\section{Email address:}

asela@unam.mx (A. D. C. Rodríguez-Varela), adolfocg@unam.mx (A. Cruz-Gómez), hvazquez@campus.iztacala.unam.mx (H. Vázquez-López),nerak_anex@hotmail.com (K. Hernández-Pérez), luisdohko@hotmail.com (L. R. Palacios-Navarro)

\section{To cite this article:}

Rodríguez-Varela Asela Del Carmen, Cruz-Gómez Adolfo, Vázquez-López Horacio, Karen Hernández-Pérez, Luis Roberto Palacios-Navarro. Ichthyofauna in the Xhimojay Dam, State of Mexico. American Journal of Life Sciences. Vol. 3, No. 3, 2015, pp. 184-189.

doi: 10.11648/j.ajls.20150303.19

\begin{abstract}
The State of Mexico has a large number of reservoirs that have the conditions necessary to host the life of freshwater fish, such is the case of Xhimojay dam for which there are no studies on the fish community. The objective of the present study was to determine the species of fish in the dam Xhimojay, State of Mexico, during the annual cycle 2013. Monthly samplings were made; the characteristics of habitat were recorded and collect organism for subsequent analysis in the laboratory. The physicochemical parameters which had a greater fluctuation in the system were deep and transparency. Four families were recorded where each family filed a species: Chirostoma jordani, Girardinichthys multiradiatus, Heterandria bimaculata and Cyprinus carpio, the most abundant species was G. multiradiatus with 1496 individuals and the species with smaller number of registered organisms was $\mathrm{H}$. bimaculata with 121 . The greatest diversity was presented in October and the lowest diversity was recorded in June. The species with the highest value of ecological importance was G. multiradiatus being that the physical and chemical parameters that characterize the environment favoring their presence.
\end{abstract}

Keywords: Ecology, Chirostoma jordani, Girardinichthys multiradiatus, Heterandria bimaculata, Cyprinus carpio, Ichthyology, Estado de México, Reservoir

\section{Introduction}

The freshwater ichthyofauna of Mexico consists of about 506 fish species in 47 families, this represents $6 \%$ of freshwater species known on the planet. The importance of the ichthyofauna in Mexico due to the high level of endemism, of total species recorded, 163 (32\%) are endemic to the country (De la Vega, 2006). The State of Mexico has a lot of continental systems with the necessary conditions to host the life of freshwater fish (Cruz-Gómez et al., 2010), the importance of studying these river systems whose main objective is to understand the mechanisms and processes responsible for the differences and/or similarities between communities and their relationship with physicochemical characteristics of the water where they develop (Torres et al., 2006). Most of the works about lotic systems on State of Mexico, focuses on trophic aspects (Navarrete-Salgado et al., 2007a), reproductive (Cruz-Gómez et al., 2010, 2011, 2013), or have been made in large tracts of Mexican territory (Méndez-Sánchez et al., 2002; Morales-Ortiz and
Gutiérrez-Yurrita, 2003), however there are few community work in areas of lesser extent such as the case of Xhimojay dam, in which there has been no study of the ichthyofauna. Because of this, the present work aims to identify fish species present in said body of water.

\section{Material and Methods}

\section{Study Area}

The Xhimojay dam is located in the municipality of Jilotepec, located to the Northwest of the State of Mexico, is located between the coordinates $99^{\circ} 26^{\prime} 37^{\prime \prime}$ as a minimum and $99^{\circ} 44^{\prime}$ '02" 'West longitude as maximum, and at coordinates $19^{\circ} 52^{\prime} 02^{\prime \prime}$ minimum and $20^{\circ} 12^{\prime} 43^{\prime \prime}$ as maximum, at an average altitude of 2440 meters above sea level (masl), hydrological State of Mexico letter shows that Jilotepec belongs to the hydrologic region of Alto Panuco (Jilotepec, 2013). 
Monthly samples were performed from January to December 2013 in the north and south of the Xhimojay dam (Fig. 1). At each sampling collection sites were georeferenced with a Magellan Map 410 GPS, were recorded physicochemical parameters depth and transparency with a Secchi disc Water Mark, the water temperature and conductivity with a conductivitymeter YSI 30, dissolved oxigene with OAKTON DO 300 Oximeter; $\mathrm{pH}$ with digital potentiometer ORION 290 WD-35624-74 and water color with the Forel-Ule scale as indirect method to measure productivity of the system.



Figure 1. Location of sampling stations in Xhimojay dam. Markers indicate locations where the physicochemical and environmental characteristics were recorded.

The collection of organisms was performed according to the habits reported for the species. Contreras (2005), Miller et al. (2005) and work done by the research group of the Fish Ecology Laboratory of the Facultad de Estudios Superiores Iztacala, UNAM (LEPFESI, UNAM) in the reservoirs Ignacio Ramírez, Salazar, Villa Victoria, Huapango and La Goleta in the State of Mexico and San Martín in State of Queretaro, have shown that in these places fish live associated to the shore where submerged vegetation and find shelter and food. Due to these features the art of capturing more suitable for this type of environments, habits, and size of the fish, is the aquatic bottom net trademark WaterMark of aluminium structure with rectangular mouth of $25.4 \times 45.72$ $\mathrm{cm}$, with $25.4 \mathrm{~cm}$ deep, aperture of $500 \mu \mathrm{m}$ and handle of $152.4 \mathrm{~cm}$ (net approved by the United States Environmental Protection Agency for reliable sampling of organisms in rivers, lakes, preys or reservoirs) At each sampling were performed on average $116.25 \mathrm{~m}^{2}$ of drag on submerged vegetation.

The captured organisms were fixed in $10 \%$ formalin and transferred to LEPFESI, UNAM. The organisms were identified using specific keys (Miller et al., 2005). The abundance was standardized in individuals $/ 100 \mathrm{~m}^{2}$ and grams $/ 100 \mathrm{~m}^{2}$.

The specimens were sexed and measured in their pattern length with a digital Vernier caliper carbon fiber Traceable brand $15 \mathrm{~cm}$ with an accuracy of $\pm 0.01 \mathrm{~mm}$ and weighed with a digital scale Acculab VI-1 with a capacity of $120 \mathrm{~g}$ and $0.001 \mathrm{~g}$ of accuracy. The fish were grouped in frequency of sizes for analysis, at intervals of three $\mathrm{mm}$ in length.

It was determined the value of ecological importance (VEI $300 \%$ ) from the relative dominance, relative density, and relative frequency. The ecological diversity was estimated using the Shannon-Wiener index $\left(\mathrm{H}^{\prime}\right)$ using the logarithm base 10 , evenness $\left(\mathrm{J}^{\prime}\right)$ using Pielou index, and dominance using the inverse of evenness index obtained from the program PRIMER 6 v.6.1.6 (Brower et al., 1998; Clarke and Warwick, 2001; Krebs, 2014).

\section{Results}

In Table 1 the values of the mean and standard deviation of the physicochemical parameters recorded on the Xhimojay dam during the annual cycle 2013 are presented. The system was characterized as temperate $\left(20.86{ }^{\circ} \mathrm{C}\right)$, oversaturated dissolved oxygen $(8.77 \mathrm{mg} / \mathrm{L})$, with a high damping capacity (pH 9.39) and hard water (conductivity of $144.27 \mathrm{mS}$ ).

Were collected 3053 organism corresponding to four species and four families: Atherinopsidae represented by Chirostoma jordani (Woolman, 1894), Goodeidae by Girardinichthys multiradiatus(Meek, 1904), Poeciliidae by Heterandria bimaculata (Heckel, 1848) and Cyprinidae represented by Cyprinus carpio (Linnaeus, 1758).

The best represented species was G. multiradiatus with 1501 females and the species with less number of organisms was $H$. bimaculata with 121 males (Fig. 2).

The VEI demonstrated than females of G. multiradiatus are organisms of greatest importance with $89.7 \%$, while males of $H$. bimaculata were those of lower VEI with $24.71 \%$ (Fig. 3).

It was estimated the value of diversity $\left(\mathrm{H}^{\prime}\right)$ and evenness $\left(\mathrm{J}^{\prime}\right)$ of the months sampled during the study. October was the most diverse month with a value of 0.74 and an evenness of 0.95 (Fig. 4).

Table 1. Values of the physicochemical parameters recorded on the Xhimojay dam.

\begin{tabular}{lll}
\hline Parameter & Mean & SD \\
\hline Altitude $(\mathrm{m})$ & 2639.1818 & 26.9623 \\
Ambient temperature $\left({ }^{\circ} \mathrm{C}\right)$ & 22.4455 & 2.7983 \\
depth $(\mathrm{cm})$ & 57.0089 & 22.2298 \\
transparency $(\mathrm{cm})$ & 30.3690 & 17.5165 \\
water temperature $\left({ }^{\circ} \mathrm{C}\right)$ & 20.8630 & 3.0029 \\
disolved oxygen $(\mathrm{mg} / \mathrm{L})$ & 8.7785 & 1.5688 \\
conductivity $(\mathrm{mS})$ & 144.2763 & 46.0401 \\
$\mathrm{pH}$ & 9.3946 & 1.5419 \\
\hline
\end{tabular}




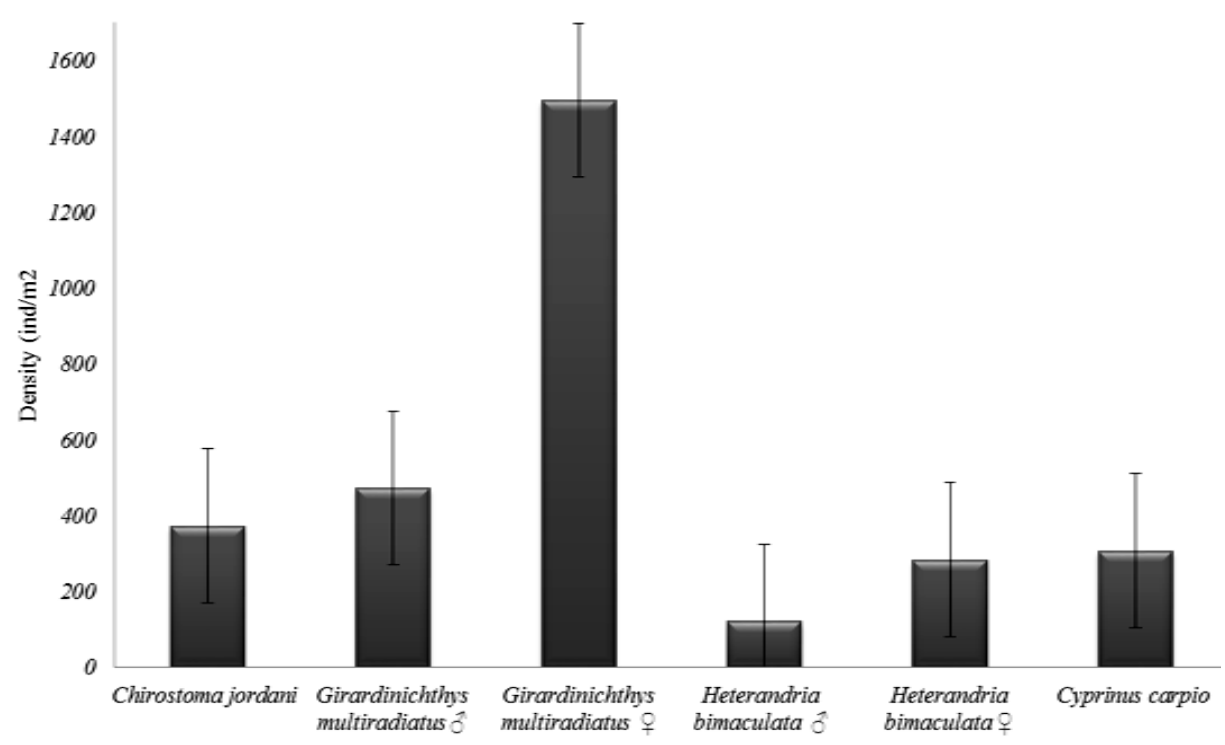

Figure 2. Annual abundance of the fish community of the Xhimojay dam during 2013.

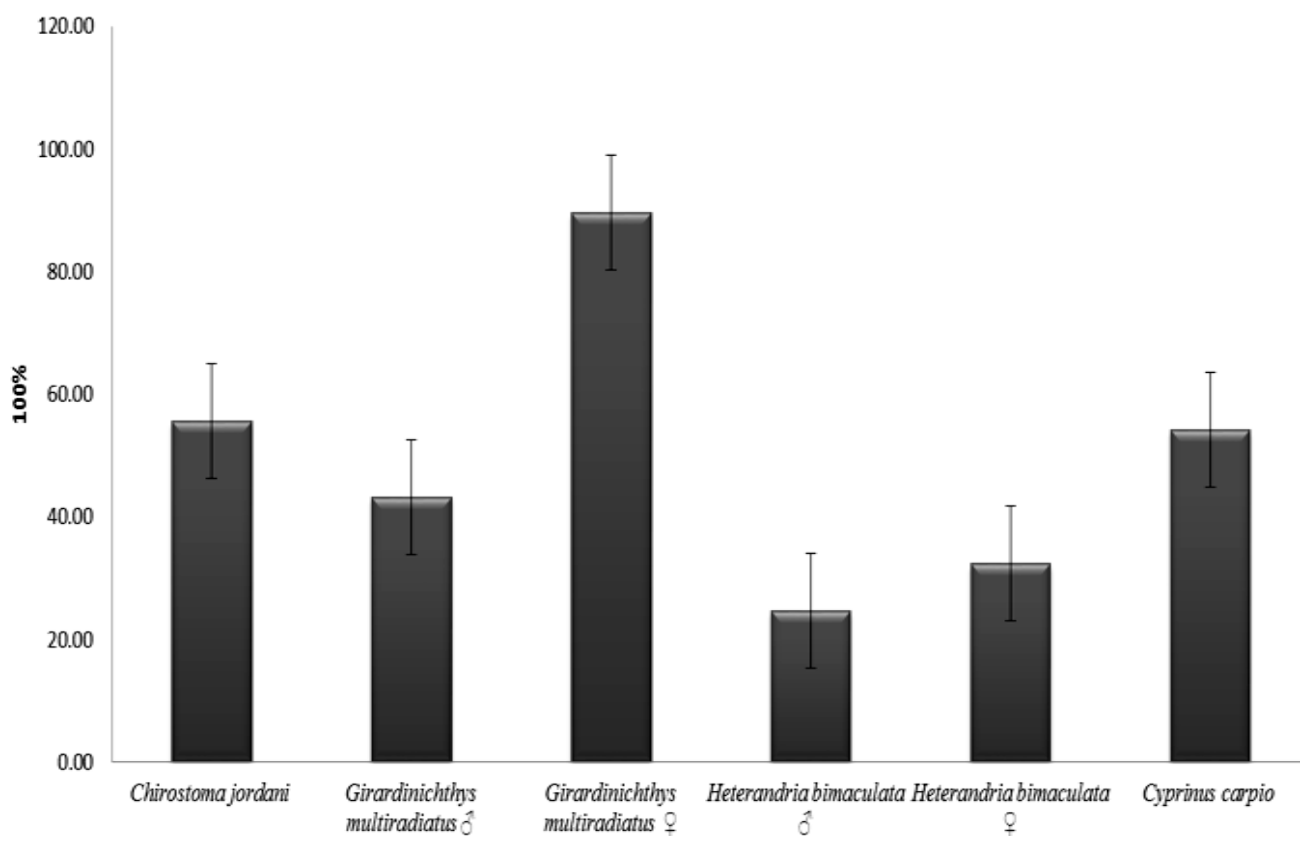

Figure 3. Value of annual ecological importance of the Xhimojay dam, 2013.

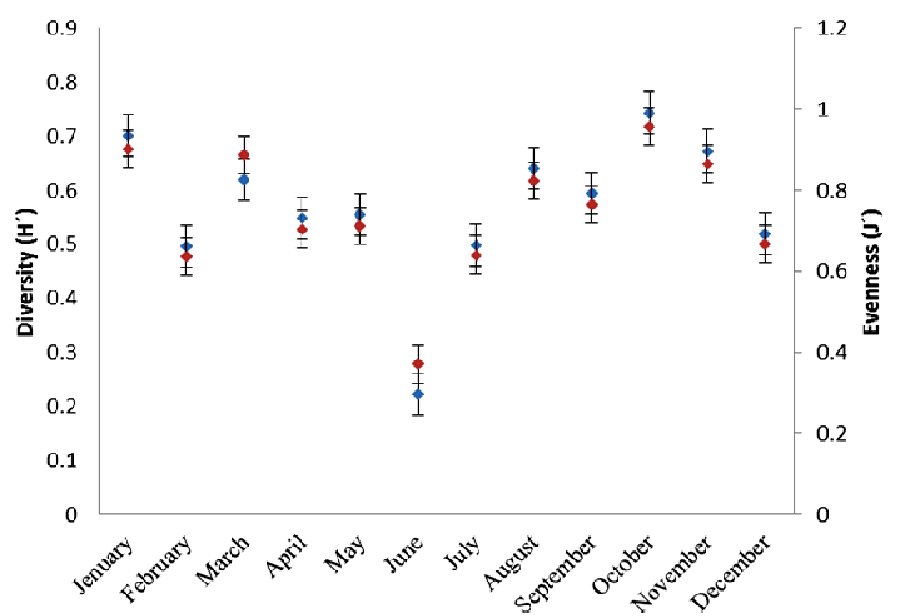

Figure 4. Diversity $\left(H^{\prime}\right)$ and evenness $\left(J^{\prime}\right)$ of the fish community of the Xhimojay dam, 2013. 


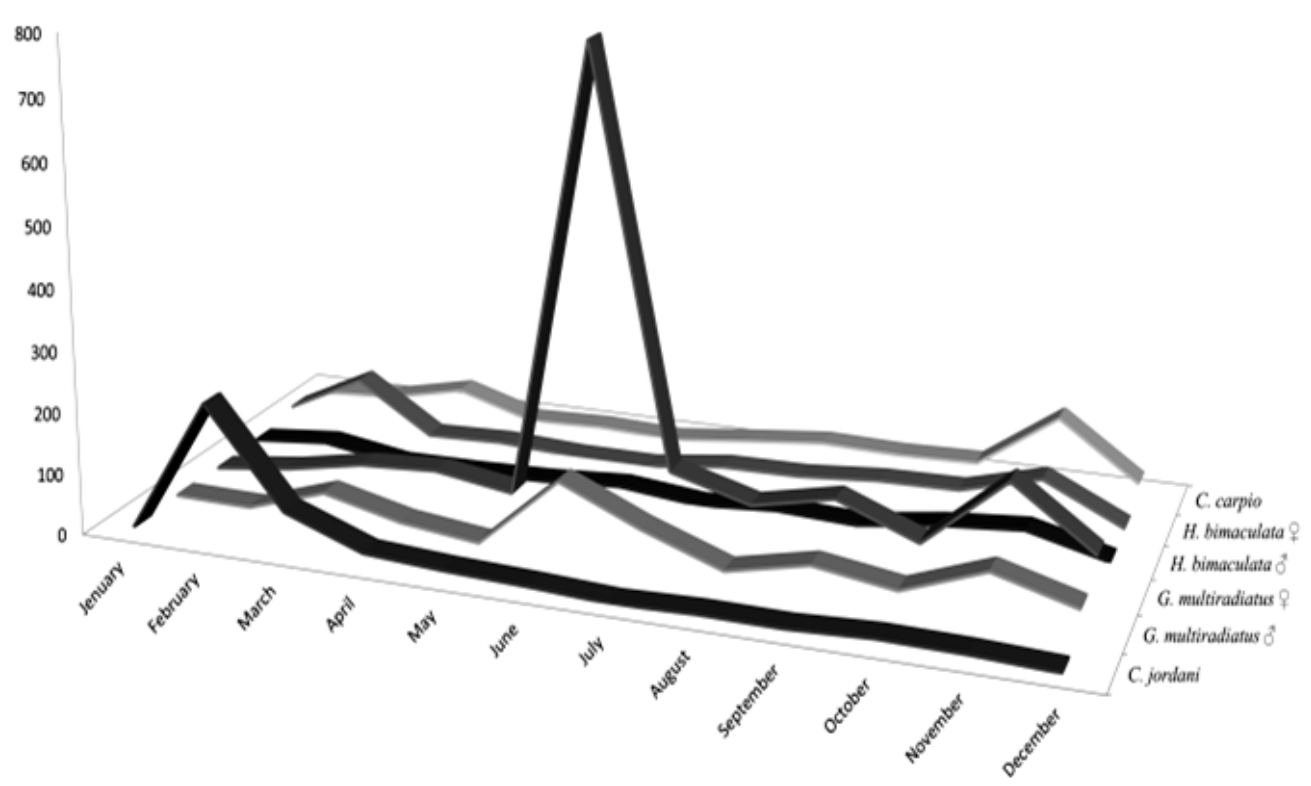

Figure 5. Density by species (ind/100 $\mathrm{m}^{2}$ ) collected at the Xhimojay dam during the 2013.

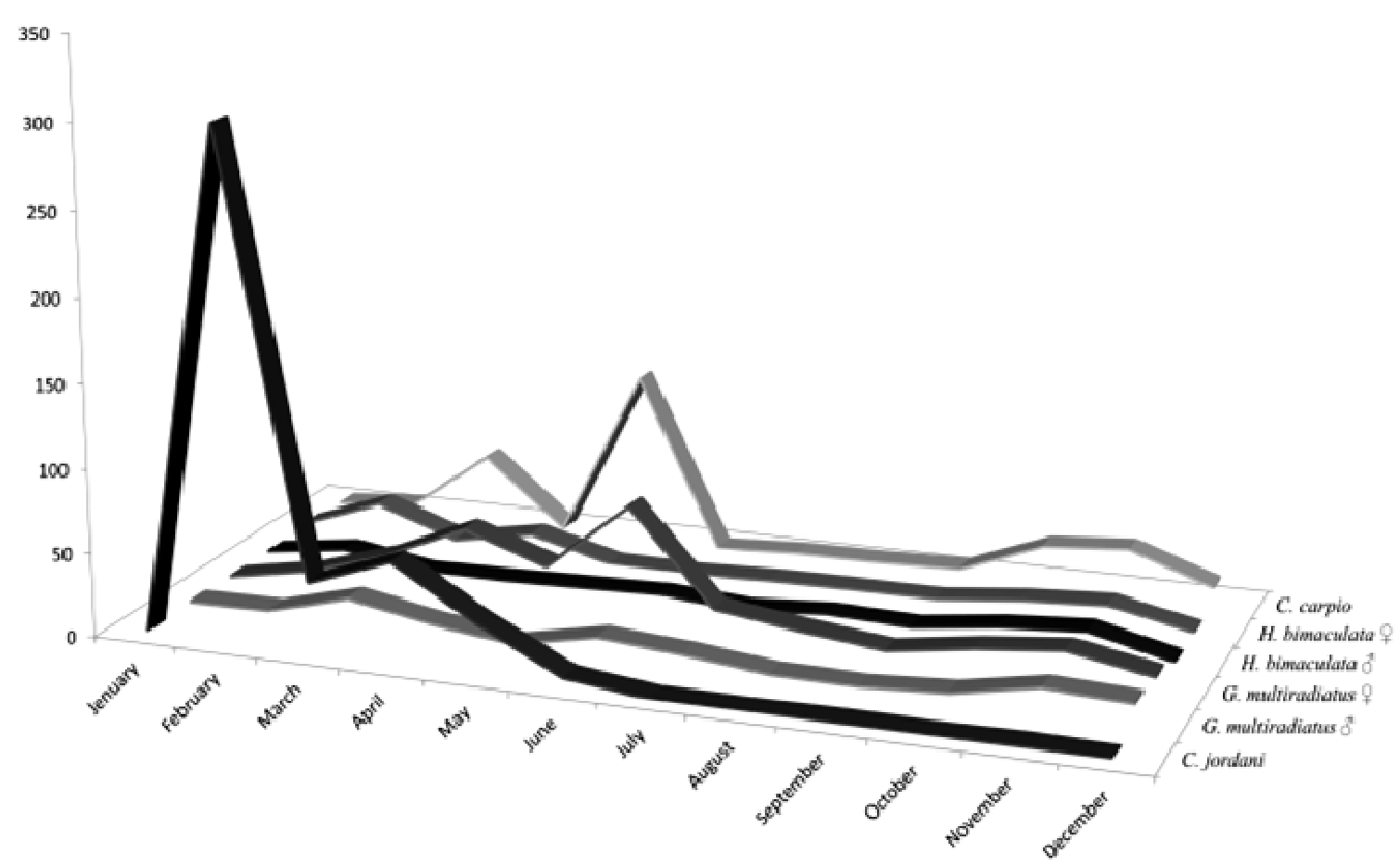

Figure 6. Biomass by species $\left(\mathrm{g} / 100 \mathrm{~m}^{2}\right)$ collected in the Xhimojay dam during 2013.

\section{Discussion}

The water from the Ximohay dam is considered temperate, hyperoxigenated, with a strongly alkaline $\mathrm{pH}$ and a shallow continental system (Gama et al., 2010), physicochemical parameters that showed the greatest fluctuation in the system were depth, $\mathrm{pH}$ and transparency.

The species collected in this study do not differ from those recorded for the State of Mexico despite the environmental deterioration suffered by systems for the extraction of water for drinking water supply and crop species for human consumption, they bring as a consequence an increase in exotic species, causing the displacement of native species (Méndez-Sánchez et al., 2002).

Méndez-Sánchez et al. (2002) registered $C$. jordani and $G$. multiradiatus (endangered species) in different basins of the State of Mexico as endemic species of the central plateau, the distribution of these species in the study area may be because that the Panuco functions as an ecological corridor between the fauna, both the Nearctic and Neotropical regions and both species are considered from lermense origin (Nearctic) which recently entered to the Pánuco basin (Morales-Ortiz and Gutiérrez-Yurrita, 2003).

Heterandriabimaculata was introduced accidentally to the 
water bodies of the State of Mexico for aquacultural activities, while C. carpio is an introduced species based aquaculture/fisheries due to its rapid growth and adaptability, which gives a high commercial value (Contreras-MacBeath et al., 2014).

Heterandria bimaculata showed a greater number of individuals in the months of October, November and February (Fig. 5), Gómez et al., (1999) mention that this species has its reproductive stage from July to September; likewise the number of females was higher because males have a high precocity compared to females awaiting reach a larger, mortality of males rises because its ornamentation puts them at greater risk predation (Gómez et al., 1999). The greater abundance of $C$. jordani was recorded in the months of February and March (Fig. 5) and its biomass was significantly higher than the other species in the same period (Fig. 6), this can be attributed to found the necessary food to increase its size and weight during these months (Olvera-Blanco et al., 2009). C. jordani competes directly with $C$. carpio for resources in the area, since the diet of both is similar (Navarrete-Salgado et al., 2010) which may explain the abundance of these organisms is similar.

Despite the introduction of $H$. bimaculata in the dam, was recorded a number of organisms greater of $G$. multiradiatus in comparison to the other species inhabitants of the place, the high abundance of females can be attributed to environmental characteristics of the zone, because they favored its development throughout the annual cycle studied, since this species has preferences towards the shallow areas that are at the edge of the water bodies (Navarrete-Salgado et al., 2007b), and this is where the weeds and aquatic vegetation is located and they can find shelter from predators, is the area of courtship and have greater chances of finding food (CONANP, 2014). June was the month in which the species was more abundant with 782 organisms (Fig. 5.), this is due to the large number of births present during this month, because of the total collected, the $35.29 \%$ corresponds to hatchlings which explains the low biomass obtained compared with April (Fig. 6), where despite the observed low values of abundance, biomass increased by the presence of fish sizes ranging from two to $4.8 \mathrm{~cm}$; since they are viviparous fish according to the biology of the species, Rush-Miller (2009) mentions that the reproduction season covers from December to May, explaining the observed in the months mentioned above. Because of this June presented the lowest values of diversity compared to the other months $\left(\mathrm{H}^{\prime}=0.22\right.$ decits) (Fig. 3), which suggests that the species $G$. multiradiatus had the necessary conditions to increase its birth rate during that month, which directly influences the value of importance, being $G$. multiradiatus the most important species with $89.67 \%$ (Fig. 4).

Trujillo-Jiménez and Espinosa de los Monteros (2006) mention that the distribution of the godeids is far from being natural, since the modifications of habitat in practically all of the basins where this family is distributed is reflected in the restriction of the distribution of most of these species. Populations of G. multiradiatus, are distributed in the lakes of
Parque Nacional lagunas de Zempoala, Morelos, Mexico and along to the Alto Lerma, because this is an endemic organism of the Lerma basin River, this agrees with that reported by Méndez-Sánchez et al., (2002), who mentioned that $G$. multiradiatus is one of the four endemic species within the Panuco, where are already reported cases of three species extinct specifically to the area of influence of the urban area of the State of Mexico and Federal District (D. F.), near Teotihuacan, that is, although a high abundance of $G$. multiradiatus was recorded during the 2013 annual cycle in a short time could cause the extinction of this if it lead to changes that influence negatively the place.

The highest value of diversity (74\%) occurred in October, this due to the biology of organisms and the highest levels of depth $(74 \mathrm{~cm})$ that showed no drastic changes with respect to the other months, these changes are caused by habitat characteristics and use of reservoir water by anthropogenic activities carried out on site (De la Vega, 2006), therefore to appear less changes in depth, the system showed greater stability, and to have a greater depth this caused that the fish to make better use of the food resource, which benefits the growth of the species in the system (Elíasand Navarrete, 1998).

We can concluded that Xhimojay dam is a temperate, hyperoxygenated, alkaline and shallow system normal conditions to such water bodies and belonging to the hydrologic region of Panuco, the composition of the fish community of Xhimojay dam during the annual cycle 2013 consists of four species corresponding to four families, the dominant species is G. multiradiatus since the physical and chemical parameters that characterize the environment and habitat conditions favor their presence and G. multiradiatus is the species most ecologically important and necessary studies on this species, it is endemic and threatened by the use given to systems where it is distributed.

\section{Acknowledgements}

The authors thank the National Autonomous University of Mexico (UNAM) through the career of Biology of FES Iztacala, Project Support Program Innovation and Improvement of Teaching (PAPIME), Project EN203804 and Support Program Career Teachers to Promote Research Groups (PAPCA), for their support in the purchase of materials and equipment for conducting fieldwork.

\section{References}

[1] De la Vega M.Y., 2006. Estado de conservación de los peces de la familia Goodeidae (Cyprinodontiformes) en la mesa central de México. Revista de Biología Tropical, 54:163-167.

[2] Cruz-Gómez A., A.C. Rodríguez-Varela and H. Vázquez-López, 2010. Madurez sexual y reproducción de Girardinichthys multiradiatus (Meek, 1904) en un embalse del poblado de San Martín, Querétaro, México. BIOCYT, 3:94-106. 
[3] Torres Y., G. Roldán, S. Asprilla and T.S. Rivas, 2006. Estudio preliminar de algunos aspectos ambientales y ecológicos de las comunidades de peces y macroinvertebrados acuáticos en el río Tutunendo, Chocó, Colombia. Revista de la Academia Colombiana de Ciencias Exactas, Físicas y Naturales, 30:67-76.

[4] Navarrete-Salgado N.A., J.R. Aguilar, J.M.D. González and G.F. Elías, 2007a. Espectro trófico y trama trófica de la ictiofauna del embalse San Miguel Arco, Soyaniquilpan, Estado de México. Revista de Zoología, (18):1-12.

[5] Cruz-Gómez A, A.C. Rodríguez-Varela and H. Vázquez-López, 2011. Reproductive aspects of Girardinichthys multiradiatus, Meek, 1903 (Pisces: Goodeidae). BIOCYT, 4:215-228.

[6] Cruz-Gómez A., A.C. Rodríguez-Varela and $\mathrm{H}$. Vázquez-López, 2013. Reproductive aspects of yellow fish Girardinichthys multiradiatus (Meek, 1904) (Pisces: Goodeidae) in the Huapango Reservoir, State of Mexico, Mexico. American Journal of Life Sciences, 1:189-194.

[7] Méndez-Sánchez J.F., E. Soto, J.P. Maya and M.A. Hernández, 2002. Ictiofaunadel Estado de México. Ciencia Ergo Sum, 1:87-90.

[8] Morales-Ortiz J.A. and P.J. Gutiérrez-Yurrita, 2003. Ictiofauna de la cuenca del río Moctezuma. Primer lugar del Premio otorgado por el Consejo de Ciencia y Tecnología del Gobierno del Estado de Querétaro en el área de Sustentabilidad del Recurso agua en Querétaro. Disponible sólo en formato digital en la recopilación "Mejores trabajos del Simposium El quehacer de la Ciencia en Querétaro -2003-"México.

[9] Jilotepec, 2013. Diagnóstico y estadística municipal (Extracto del plan de desarrollo municipal 2013-2015). Municipio de Jilotepec, Estado de México: 148 pp.

[10] Contreras M.T., 2005. Monitoreo de poblaciones de Amblystoma zempoalensis, Girardinichthys multiradiatus y Cambarellus zempoalensis dentro del área de protección de flora y fauna Corredor Biológico Chichinautzin-Parque Nacional Lagunas de Zempoala. $<$ http://chichinautzin.conanp.gob.mx/proy_esp_acuat.hatm> (accessed November 20, 2014).

[11] Miller R.R., W.L. Minckley and S.M Norris, 2005. Freshwater fishes of México. The University of Chicago Press, U.S.A: 490 pp.

[12] Brower J.E., J.H. Zar and C.N. Endee, 1998. Field and laboratory methods for general ecology. 4. WCB McGraw-Hill, USA: $273 \mathrm{pp}$.

[13] Clarke K.R. and R.M. Warwick, 2001. Change in marine communities: An approach to statistical analysis and interpretation. 2. PRIMER-E: Plymouth: $180 \mathrm{pp}$.
[14] Krebs C.J., 2014. Ecological methodology. In press.

[15] Gama J.L.F., E.L.M. Pavón, T.P. Ramírez and O.A. López, 2010. Análisis de calidad de agua. Relación entre factores bióticos y abióticos. UNAM, FES Iztacala. México: 115 pp.

[16] Contreras-MacBeath T., M.T. Gaspar-Dillanes, L. Huidobro-Campos and H. Mejía-Mojica, 2014. Peces invasores en el centro de México, p. 413-424. In: R. Mendoza, P. Koleff (eds.), Especies acuáticas invasoras en México. Comisión Nacional para el Conocimiento y Uso de la Biodiversidad, México.

[17] Gómez M.J., J.L. Guzmán and A. Olvera, 1999. Reproducción y crecimiento deHeterandria bimaculata(Cyprinodontiformes: Poeciliidae) en la Laguna "El Rodeo", Morelos, México. Revista de Biología Tropical, 47:581-592.

[18] Olvera-Blanco Y.M., J.L. Gómez-Márquez, B. Peña-Mendoza, M.T. Gaspar-Dillanes and C. Pérez, 2009. Reproductive biology of Menidia jordani (Atheriniformes: Atherinopsidae) in Xochimilco Lake, Mexico. CienciaPesquera, 17:65-75.

[19] Navarrete-Salgado N.A., G. Contreras-Rivero and D.L. Jacobo-Segura, 2010. Situación de Menidia jordani (Pisces: Atherinopsidae) en el embalse La Goleta, Estado de México. RevistaChapingo. SerieCienciasForestales y delAmbiente, 16:165-169.

[20] Navarrete-Salgado N.A., B.E. Cedillo-Díaz, G. Contreras-Rivero and G. Elías-Fernandez, 2007b. Crecimiento, reproducción y supervivencia de Girardinichtys multiradiatus (Pisces, Goodeidae) en el embalse San Miguel Arco, Estado de México. RevistaChapingo. SerieCienciasForestales y delAmbiente, 13:15-21.

[21] CONANP, 2014. Corredor biológico Chichinahuitzin: Mexcalpique.

$<\mathrm{http}$ //chichinautzin.conanp.gob.mx/especies/mexcalpique.ht $\mathrm{m}>$ (accessed November 20,2014).

[22] Rush-Miller R., 2009. Peces dulceacuícolas de México. Comisión Nacional para el Conocimiento y Uso de la Biodiversidad, Sociedad Ictiológica Mexicana AC., El Colegio de la Frontera Sur y Consejo de los Peces del Desierto México-Estados Unidos. México, DF: 459 pp.

[23] Trujillo-Jiménez P. and E.V. Espinosa de los Monteros, 2006. La ecología alimentaria del pez endémico Girardinichthys multiradiatus (Cyprinidontiformes: Goodeidae), en el Parque Nacional Lagunas de Zempoala, México. Revista de Biología Tropical, 54:1247-1255.

[24] Elías G. and N.A. Navarrete, 1998. Crecimiento y producción de carpa común (Cyprinus carpioLinnaeus, 1758) durante la época de sequias y lluvias en un bordo del Estado de México, México. Hidrobiológica, 8:117-123. 